\title{
A Framework for Developing the Knowledge and Competencies of the Outside School Hours Services Workforce
}

\author{
Jennifer Cartmel and Kylie Brannelly
}

\begin{abstract}
A skilled workforce is critical to the delivery of quality school age care services. A strategy' called Core Knowledge and Competency (CKC) Framework was designed to build the skills and knowledge of after school care educators as they provided before and after school programs in Queensland, Australia. The strategy was to help educators meet the Australian National Quality Standard for Early Childhood Education and Care and School Age Care (National Quality Standards) (NQS). This atticle describes the use of realist evaluation principles to examine the implementation of this strategy. Improvements to the quality of the workforce were reported including less staff turnover, increased capacity and competence of educators which would result in enhanced outcomes for children. However the implementation of the strategy relied on highly competent leaders within the services.
\end{abstract}

Keywords: workforce development, mentors, school-aged care, leadership, child development

\section{Introduction}

Staff in before and after school services have the highest rate of under-qualification in the Australian care and education sector, which contributes to the low status of outside school hours (OSH) within the children's services sector (Simoncini \& Lasen, 2012). There is a need for training and appropriate qualifications to equip educators to problem solve and respond appropriately to the demand for high quality services as assessed by the National Quality Standard (NQS) (ACECQA, 2013c). Due to the low pay and the status of the OSH profession, educators are often unwilling to undergo the further training and professional development needed to deliver quality SAC services to children (Simoncini, Cartmel, \& Young, 2015; Simoncini \& Lasen, 2012). Further, in relation to staff recruitment and training, when staff turnover is high there are concerns about a lack of continuity of care for children and problems for services in the amount of time required to train staff (Cartmel \& Hayes, 2016). In response to these challenges, Queensland Children's Activities Network (QCAN), a membership organisation that provides advocacy and training for the school age care sector, devised a strategy known as the Core Knowledge and Competency Framework (QCAN, 2014a). 
The Core Knowledge and Competency Framework (CKC) for Outside School Hours services (OSH) is a program of professional development to support educators in before and after school hours services to undertake their roles and responsibilities in improving outcomes for children. The Framework was developed by QCAN from a strong theoretical base around the expertise educators require in order to work with children in outside school hours services (QCAN, 2014a; 2014b). The CKC Framework contains information about child development and has a strong emphasis on building relationships and fostering critical reflection. The CKC Framework contains 10 areas of knowledge, skills and competence including:

- Child/Youth Growth and Development;

- Learning Environments and Curriculum

- Child/Youth Observation and Assessment

- Interactions with Children and Youth

- Engagement with Children and Youth

- Cultural Competency and Responsiveness

- Family, School and Community Relationships

- Safety and Wellness

- Program Planning and Development

- Professional Development and Leadership

Each area of knowledge was further divided into five levels of competence. Level 1 Educators with minimal experience/new Educators (without or working towards formal qualification). Level 2 -Educators with increased knowledge \& skills (working towards or holding Certificate level qualification). Level 3,4 \& 5-Educators with capacity to undertake a mentoring role. Each level is a prerequisite to the next, with knowledge and skills in one level required before moving to the next. The progression of knowledge and skills in the Framework builds from a foundation of knowing and understanding practice, to the application of that knowledge in the planning and implementing of experiences, to being able to analyse and evaluate programs and practices more skilfully. The format of the Framework was a manual of written information with self assessment checklists for each of the levels of competence. It was designed as a tool for educators to self assess their knowledge and competencies in conjunction with a mentor - usually the leader of the OSH service. It was based on the principle that enhanced problem solving skills and decision making capacities enable educators to link theory to practice, significantly improving outcomes for them as learners (Kielblock \& Monsen, 2016; Keen, 2011). Problem solving frameworks provide a clear process for this to occur. The CKC Framework was based on training principles linked to on the job learning which allowed the educators to actively participate in the OSH sector whilst learning.

It was the intention of the CKC Framework to support critical thinking through confronting pre-suppositions and ways of thinking by "closely examining all aspects 
of events and experiences from different perspectives" (DEEWR, 2011, p. 11), The Framework required educators to reflect on their own understanding and practices through the support of the mentor and the resources of the Framework. Educators (following training and support) use the phases of critical thinking involved in the process of embedding sound research and theory into effective and sustainable applied practice, which makes a difference for children and young people and those close to them (Kielblock \& Monsen, 2016; Marschark \& Johnson, 2008). When educators imbed critical thinking in their practice, they begin to question generally accepted paradigms about the care and education of children (Macfarlane, Casley, Cartmel, \& Smith, 2014) whilst linking contemporary theories to practice (Cartmel et al., 2015; Davies \& Dart, 2005). Educators "utilising problem-solving as a part of critical reflection enables the construction and reconstruction of new knowledge" (Macfarlane et al., 2015, p. 331). Consequently educators in school age care services are able to imbed new thinking and practice into their programs, leading to transformational change (Mezirow, 1997) and ultimately improving outside school hours learning environments for diverse children and families engaging in the service (Brown \& Lan, 2014; Elliot, Lawrence, \& Ross-Raynor, 2008; Guilfoyle et al., 2010).

In Australia, the OSH workforce is drawn from a variety of disciplines (child care, education, health, arts, sport and recreation), which do not necessarily effectively prepare educators for work within the sector. In addition to this, the workforce continues to comprise of a large number of educators who do not hold, and are not expected to work towards any formal qualification (ACECQA, 2013a; ACECQA, $2013 \mathrm{~b}$ ). The diverse pool of educators from which the workforce is drawn adds a richness to school age children's leisure time pursuits, that if limited could be detrimental to the programs offered to children. However, the lack of qualifications has raised concerns about the quality of the service delivery (ACECQA, 2016).

This paper reports on the evaluation of the implementation of the CKC Framework. Realist Evaluation principles (Pawson \& Tilley, 1997) were used to determine how the program works rather than providing a success or failure assessment of its effectiveness (Pawson \& Tilley, 1997; Bonell et.al, 2012; McEvoy \& Richards, 2003; Pawson, 2006). The hypothesis was that an effective self assessment tool (including a resource manual and self assessment booklet supported by leaders within the OSH services would counter the problems identified within the workforce. This evaluation intended to examine how the CKC Framework provided training to the educators in Queensland services.

\section{Research Design}

\section{Realist Evaluation}

Realist Evaluation is a theory-driven approach to the evaluation of social programs, developed in response to interest in understanding how interventions or social programs work (Bonell et al., 2012; McEvoy \& Richards, 2003; Pawson \& Tilley, 
1997; Pawson, 2006). Traditional methods of review focus on measuring and reporting on program effectiveness. These methods are not easy to administer and often provide little or no clue as to why the intervention worked or did not work when applied in different contexts or circumstances, deployed by different stakeholders, or used for different purposes. Pawson \& Tilley (1997) argued that programs are often introduced within complex social systems which are in constant transformation, and therefore evaluation needs to take into account the context within which they are implemented. As such, Realist Evaluation is useful in terms of understanding why an intervention produces dissimilar outcomes when implemented in different settings. It describes what mechanisms (how people interpret and act upon ideas and opportunities presented by the program) cause which outcome (intended or unintended consequences) and in which context (social and cultural conditions external to the interventions) (Pawson \& Tilley, 1997). The use of Realist Evaluation provides an explanatory analysis aimed at discerning what works for whom, in what circumstances, in what respects and how. This methodology was appropriate to evaluate the effectiveness of CKC Framework, which had been developed from a body of knowledge about the understandings and expertise required for the workforce in outside school hours programs. The methodology uses Context-Mechanism-Outcome (CMO) configuration to organise the research process.

The research methodology has three phases within the research approach. These 3 phases have been summarised in Table 1 .

Table 1. Overview of The Realist Evaluation Process for CKC Framework (Pawson \&.Tilley, 1997) and data sources.

\begin{tabular}{|c|c|c|}
\hline Phases & Source of data and activity & Participants \\
\hline $\begin{array}{l}\text { Phase } 1 \\
\text { Identification of CKC Framework } \\
\text { program theory or hypotheses about } \\
\text { Context-Mechanism-Outcome (CMO) } \\
\text { configurations }\end{array}$ & $\begin{array}{l}\text { - Review of the Core Knowledge } \\
\text { Competencies - National After School } \\
\text { Alliance (REF) } \\
\text { - Systematic review - workforce } \\
\text { development } \\
\text { - Interview }\end{array}$ & - QCAN staff \\
\hline $\begin{array}{l}\text { Phase } 2 \\
\text { Implementation - Testing the } \\
\text { program theory }\end{array}$ & $\begin{array}{l}\text { - Pre and post surveys } \\
\text { - Follow up intervlews and focus groups of } \\
\text { leaders } \\
\text { - Facilitator Journals }\end{array}$ & $\begin{array}{l}\text { - OSH services } \\
\text { leaders and } \\
\text { educators }\end{array}$ \\
\hline $\begin{array}{l}\text { Phase } 3 \\
\text { Refining the program theory }\end{array}$ & $\begin{array}{l}\text { - Analyses and interpretation } \\
\text { - Refined Context-Mechanism-Outcome } \\
\text { (CMO) configurations }\end{array}$ & - QCAN Staff \\
\hline
\end{tabular}

In each of the following sections about the participants and data collection, details about each of the phases have been described. . 


\section{Participants}

\section{Phase One}

Participants were four QCAN staff members assigned to the CKC Framework project. The staff had created the Framework and the implementation strategy. Three of the staff became the trainers associated with the implementation phase that occurred during an 18 month period.

\section{Phase Two}

Participants were the leaders and educators who attended the QCAN sessions on the CKC Framework. The participants were identified through purposive sampling by the QCAN staff who were facilitating the CKC Framework training. QCAN staff invited participants in the CKC Framework training to complete pre surveys, and then post surveys after a period of 12 months, which asked them to rate their knowledge and confidence about their work with children. In total 583 educators completed surveys $(n=329)$ mentor/leaders and $(n=254)$ educators.

Mentor/leaders were mostly female with tertiary qualifications. The tertiary qualifications of participants were vocational qualifications in children services, 58 percent, and university qualifications in education and other university degrees in different discipline areas, 42 percent. More than half the mentor/ leaders fell within the age range of $20-40$ years. Two thirds of the mentor/leaders had worked less than 10 years in the sector. These leaders were purposively selected as they had mentored educators in their services who were self assessing their knowledge and skills using the CKC Framework. Seven leaders attended a focus group and 10 leaders participated in interviews.

Three quarters of the educators were female. Thirty eight percent of educators had no qualifications. Those with qualifications had a vocational qualification in children's services. Educators ranged in age from over 17 years to older than 60 years, with nearly two thirds under the age of 30 years. 80 percent of educators had been working in the sector for less than 5 years, with 30 percent less than one year.

\section{Phase Three}

In Phase Three, the same four QCAN staff who participated in Phase One engaged in 2 focus groups to discuss their experiences and review the findings from phase two.

\section{Data collection tools}

\section{Phase One}

The data collection tools were based on a model of critical thinking. The focus group in phase one was structured around this model. The participants were encouraged to think deeply about the development of the CKC Framework materials and the implementation strategy. Further, this process was used in all of the focus groups and interviews in other phases. 


\section{Phase Two}

Data was gathered using pre and post surveys, Most Significant Change (MSC) questions (Davies and Dart 2005) as well as critical reflections (Macfarlane, Lakhani, Cartmel, Casley \& Smith, 2015; Cartmel, Macfarlane, Casley \& Smith, 2015) were used in focus groups and interviews.

The baseline survey data was intended to measure levels of confidence and knowledge before and after the leaders and educators used the CKC Framework.

The MSC questions and critical reflections aimed to explore whether the training workshops and assessment resources àssisted the leaders and educators to be a more effective workforce in outside school hours programs. There was a MSC question on the post survey and it was used in the focus groups and interviews with participants. The evaluations also examined the circumstances of the program leaders as they undertook their roles as mentors to educators in the implementation of the CKC Framework.

The surveys included questions about the knowledge and the competencies required for work in OSH services. The Leader Survey had additional questions asking about the knowledge and competence of leaders to undertake the role as a mentor to others.

\section{Phase Three}

Data was gathered using focus groups with staff from seven sites and interviews with staff from ten services were used to validate the findings collected using the other data collection tools.

\section{Findings}

\section{Phase 1 The CKC Framework}

During phase one of the Realist Evaluation, the staff at QCAN were interviewed to describe QCAN's collaboration with the National After School Association (NAA) to adapt the CKC Framework. These interviews provided the context around the development of the CKC Framework. It was noted that deductive development contributed to developing the program theory from a review of the research literature on how the CKC Framework is understood or expected to work, particularly based on the NAA Core Knowledge and Competencies (NAA, 2011). Inductive development describes the way in which the program theory was translated into an operational strategy. Observations and interviews with QCAN staff that were involved in developing the training and promotion of the Framework to the OSH sector provided the information about how the Framework was intended to be used. Consequently, formulation of the program theory from stakeholders' mental models involved drawing out the concepts of how the QCAN staff understood or anticipated the CKC Framework program would work. The CKC Framework used the material from NAA as a basis and was enhanced by QCAN staff to fit with their expectations of how best to 
support educators in Queensland OSH services, and subsequently build an effective and sustainable workforce. The interviews with QCAN staff explored their accounts of the rationale, expectations and key aspects of the implementation of the Framework.

The QCAN staff developed the CKC framework to progress educators' knowledge and skills by building a strong foundation of "knowing and understanding practice" (QCAN, 2014a, p. 3) which educators apply in order to more expertly plan, implement, analyse and evaluate their programs and practices. Their aim was to ensure educators understood each of the ten Core Knowledge and Competency areas of the CKC Framework, consistently implement these areas, and mentor others in this process. They had formulated the manual and self assessment workbooks to ensure educators and mentor/leaders maintained motivation and engagement in the process. The intention was that the learning is applied throughout the process, and the participants would use the workbooks to help them link theory to practice. The QCAN staff stated that educators' learning is an intentional process of "self-directed enquiry to create change in skills, behaviour, knowledge or attitude" (QCAN, 2014a, p. 4). The Framework was written with the intention that the OSH service was the principle environment for educators' learning and on-going professional development (QCAN, 2014b). The QCAN staff were committed to the notion that the CKC framework would be crucial to the development of capable and competent educators, and of most importance was the linking of educators' knowledge and understandings to their every day practice to ensure quality learning and development for school age children (Snow, 2011).

The core set of understandings and competencies that school age educators require to effectively carry out their role and responsibilities as described in the CKC Framework acknowledge that children and educators are experiencing constant and rapid social change, including differing learning contexts. This requires educators to become effective decision makers by engaging in reflective practice to establish effective learning goals in the outside school hours programs that support children's development and learning (QCAN, 2014a). Decision-making and problem solving requires educators to have crucial knowledge regarding school age childrens' development and learning, including the brain development of children and young people (Keen, 2011; Muthivhi, 2013). Basing this knowledge on research helps educators to make informed decisions about what programs are best for individual children's learning and development (Snow, 2011). In this way, children's developing capabilities and their abilities to determine and make decisions and contribute to their world is valued, and their competence recognised (QCAN, 2012). This is achieved when educators engage in conversations of reciprocal trust änd respect between school age children and themselves to foster opportunities for "sustained shared thinking, collaborative learning and relationship building" (QCAN, 2014a, p. 4). Building upon in-depth knowledge and understanding in collaborative decision making by "questioning, stimulating and scaffolding their thinking" (QCAN, 2014a, p.10) enhances educators' understandings of the school age children and practices within the programs they deliver. Furthermore, critical reflection of the service's program in the context of research theory provides for continuous improvement in practice directly 
contributing to better-quality learning outcomes for school age children (QCAN, 2014a; Keen, 2011).

The Framework is attuned to the Australian context for National Quality Standards for School Age Care services (ACECQA, 2013c) as it assists educators to link new theory learned and prior life experiences to their workplace experiences. It includes references to My Time, Our Place: Framework for School Age Care in Australia (MTOP) which outlines practices to support and promote children's learning (DEEWR, 2011). One of the practices identified is critical reflection and on-going learning (DEEWR, 2011, p. 11), which adds further emphasis to the understanding that educator engagement in transformational learning is achieved through critical reflection of the viewpoints and perspectives entrenched in service practices (QCAN, 2014a). Mezirow (1997) describes this as "a process of effecting change in a frame of reference... associations, concepts, values, feelings, conditioned responses...structures of assumptions through which we understand our experiences" (p. 5). The CKC Framework purports that this cannot be effectively achieved without comprehensive and correct information about school age children's development, awareness of educators' own biases, and a safe, empathetic, trusting and accepting environment (QCAN, 2014a). Additionally, this must be underpinned by research-based knowledge applied through practical and effective pedagogy (NAEYC \& SRCD 2007; Marschark \& Johnson, 2008) for educators in outside school hours programs. This occurs when research and practice is integrated through the implementation of practices that reflect current research and theory, and in turn research on practice outcomes for children and educators influence further research (Gredig, 2011). Snow (2011) defines this as "creating a 360 degree informational loop" (p. 63). Snow (2011) further states "Bridging the gap between research and practice is the best way to ensure high-quality education experiences for all children and their families" (p. 63).

The implementation of the CKC Framework relied on strong leadership within OSH service, recognising that leadership exists across all levels and is often displayed by educators not employed in formal leadership roles. It was also recognised that adult learners retain knowledge and apply it more effectively when they link theory to practice. Subsequently the CKC Framework encompasses a "relevant, engaging, active, learner-centred" (QCAN, 2014b, p. 4) learning guide for workplace leaders.

The data gathered in Phase 1 contributed to the Realist Evaluation Methodology (Pawson \& Tilley, 1997) Context Mechanism Outcome configuration as outlined in Table 2 underpinned the implementation of the CKC Framework, and was proposed to guide the evaluation process. Understandings about how to recruit and train staff, and about working with school age children were the key areas of theory that informed the program theory. The context describes the cultural, social and economic circumstances in which OSH services operate. The low status, limited qualifications and status of the OSH workforce are considered within a broader landscape. The mechanism (M) outlines the features of the CKC Framework, for example the component parts and the manner in which the QCAN trainers provide information to the OSH workforce about the Framework. The outcomes $(\mathrm{O})$ are the transformational changes to the OSH workforce intended by the CKC Framework. Having a work- 
force with deeper knowledge and competencies is likely to produce a higher quality of service to children, and be more likely to meet the National Quality Standard (ACECQA, 2103c). Furthermore, the OSH staff are more likely to stay working within the sector, reducing staff turnover.

Table 2. Proposed Context Mechanism Outcomes for CKC Framework (adapted from CMO configurations, Pawson \& Tilley, 1997).

\begin{tabular}{|c|c|c|c|}
\hline Theory Area & Context & Mechanism & Outcome \\
\hline Training of staff & $\begin{array}{l}\text { - Limited mandated } \\
\text { qualifications and high } \\
\text { expectations of leaders } \\
\text { of OSH } \\
\text { - Educator professional } \\
\text { development needs to be } \\
\text { continuous and involve } \\
\text { mentoring and readily } \\
\text { available resources } \\
\text { - Professional development } \\
\text { uses practical strategles } \\
\text { and'on the job'learning } \\
\text { - Educators need to } \\
\text { be confident and } \\
\text { knowledgeable } \\
\text { - Investment in casual staff } \\
\text { is typically low }\end{array}$ & $\begin{array}{l}\text { - Professional development } \\
\text { includes access to a } \\
\text { wide range of resources } \\
\text { that give additional } \\
\text { information about the } \\
\text { competencies } \\
\text { - Website resources are } \\
\text { readily avallable } \\
\text { - Contlnuity of professional } \\
\text { development program is } \\
\text { enhanced if they include } \\
\text { mentors and handbook. } \\
\text { - Competenclies have } \\
\text { been mapped to formal } \\
\text { vocational quallfications }\end{array}$ & $\begin{array}{l}\text { - Educators with access } \\
\text { to high quality training } \\
\text { are less likely to burn } \\
\text { out } \\
\text { - Educators using } \\
\text { effective strategies can } \\
\text { provide high quality } \\
\text { outcomes for children }\end{array}$ \\
\hline $\begin{array}{l}\text { Knowledge of OSH } \\
\text { workforce roles and } \\
\text { responsibilities }\end{array}$ & $\begin{array}{l}\text { - Diverse range of age } \\
\text { groups of children } \\
\text { - Parent's expectations } \\
\text { that children will recelve } \\
\text { appropriate care } \\
\text { - Educators are central to } \\
\text { high quality }\end{array}$ & $\begin{array}{l}\text { - Educators who } \\
\text { understand and use a } \\
\text { wide range of strategies to } \\
\text { engage with children and } \\
\text { their families }\end{array}$ & $\begin{array}{l}\text { - Meeting National } \\
\text { Quality Standards for } \\
\text { child care services } \\
\text { - Effective strategies } \\
\text { used by educators to } \\
\text { achieve high quality } \\
\text { outcomes for children }\end{array}$ \\
\hline $\begin{array}{l}\text { Recruitment of staff } \\
\text { for } \mathrm{OSH}\end{array}$ & $\begin{array}{l}\text { - Turnover of staff } \\
\text { - Teams of educators } \\
\text { collaborate to provide } \\
\text { OSH service } \\
\text { - High level of skill required } \\
\text { by OSH leaders to } \\
\text { manage complexities } \\
\text { of expectations of } \\
\text { services - ability to work } \\
\text { with children. Staff and } \\
\text { parents } \\
\text { - Staff recruited did not } \\
\text { have qualifications } \\
\text { specific to outside school } \\
\text { hours care }\end{array}$ & $\begin{array}{l}\text { - Core Knowledge and } \\
\text { Competency Framework, } \\
\text { Handbook and Self } \\
\text { Assessment guide }\end{array}$ & $\begin{array}{l}\text { - Staff understand } \\
\text { job role and see } \\
\text { themselves as a valued } \\
\text { member of a team } \\
\text { - More efficient staff } \\
\text { development processes } \\
\text { to support'time poor' } \\
\text { service leaders }\end{array}$ \\
\hline
\end{tabular}




\section{Phase 2 The Implementation}

QCAN trainers planned and delivered a series of two workshops for cohorts of leaders in OSH Services in different cities and towns across Queensland. The training groups usually had 30-50 participants at each workshop session. The content of the CKC Framework manual was used to introduce strategy to the sector: The workshops consisted of power-point presentations, digital clips and individual and groups tasks. At the conclusion of the workshops the mentor/leaders were encouraged to reflect and self-assess, to ensure that were able to achieve self assessment Level 1 \& 2 of the CKC Framework assessment. This process had to be undertaken before these leaders were to become mentors to the educators in their services who were going to engage with the CKC Framework. As the QCAN staft reviewed the pre-surveys (submitted during the training) and reflected on the discussions during the training sessions, they became acutely aware of the diversity in knowledge and competence of the cohort of leaders that they had intended to be the mentors for the educators in the implementation of the CKC Framework. The ability of the leaders to become mentors was limited by their own lack of knowledge and problem solving skills.

QCAN facilitators found they were required to provide a significant amount of additional support to leaders before they could start to recruit and engage with educators in their services. Some leaders did not even feel confident enough to explain the potential of the CKC Framework to educators. In response, QCAN staff introduced facilitated training sessions to support leaders in this task. They developed additional support material including resources about child development, adult learning, and operating school age care programs. Furthermore, these leaders/mentors requested a mentor or significant other to support them in the process.

Post training data was in the main gathered from leaders. The need to upskill the leaders so that they could undertake the role of mentors became the key focus of the QCAN trainers. Without the leaders as a key resource it was difficult to mentor educators in OSH services and expand the implementation of the program.

\section{Phase 3 How did it work?}

Interviews with the QCAN training team revealed that there was a significant need to ensure that mentor/leaders were knowledgeable and competent. Without competent and knowledgeable leaders as mentors it was not possible for the CKC Framework to work. The training and resources provided to mentor/leaders and educators as part of the program acted as facilitating mechanisms that improved their skills and confidence to undertake their job role. The program elicited positive change in the way in which mentors communicated and supported educators, and subsequently the way in which educators communicated with children. Unqualified educators were the least confident to undertake their job role. However, these educators utilising the CKC Framework, in combination with mentoring by leaders made the most significant improvement to their capacity to undertake their job roles.

The themes from the surveys, focus groups and interviews are summarised in the Content-Mechanism-Outcome format (Pawson \& Tilley, 1997). Each theory area is 
identified in Table 2 has been described by a set of CMO configurations. The context associated with each theory is described, and the mechanisms that are the features or actions associated with the intervention of the CKC Framework are listed. In the third column the outcomes of the intervention are explained (It is easier to read the findings down each column). Table 3 Training of Staff contains many comments regarding the leaders of service, and their impact on how the staff engage with opportunities for professional development. The context of the circumstances in $\mathrm{OSH}$ leaders operate is characterised by qualifications and the mechanisms included resources provided by QCAN as part of the professional development program. The leaders of OSH services contribute to create the culture of professionalism that contribute to a stable workforce.

Table 3. Theory area one: Training of staff.

\begin{tabular}{|c|c|c|}
\hline Context & Mechanlsm & Outcome \\
\hline $\begin{array}{l}\text { - Limited mandated } \\
\text { qualifications for leaders } \\
\text { and educators. } \\
\text { - Service leaders have } \\
\text { qualifications in } \\
\text { Children's Services and } \\
\text { they are often leading } \\
\text { staff teams with a diverse } \\
\text { range of qualifications. } \\
\text { - Educator professional } \\
\text { development needs } \\
\text { to be continuous and } \\
\text { involve mentoring and } \\
\text { resources such as a } \\
\text { manual. } \\
\text { - Professional } \\
\text { development used } \\
\text { practical strategies. } \\
\text { - Experiential learning is } \\
\text { important to creating. }\end{array}$ & $\begin{array}{l}\text { - Explicit links to the Framework } \\
\text { (DEEWR, 2011) and the National } \\
\text { Quality Standard (COAG, 2009) in } \\
\text { trainlng manual and workshops. } \\
\text { - Understanding adult learning and } \\
\text { skills for coaching and mentoring.. } \\
\text { - Collegial support between leaders } \\
\text { of services. } \\
\text { - Using the same professional } \\
\text { language. } \\
\text { - The CKC Framework provided more } \\
\text { detall about job responsibilities than } \\
\text { formal vocational qualifications. } \\
\text { - Training conducted onsite in outside } \\
\text { school hours care services using self- } \\
\text { assessment, Including opportunities } \\
\text { to embed staff training into weekly } \\
\text { practice. } \\
\text { - Changing weekly rosters to free up } \\
\text { some time for the staff to spend time } \\
\text { undertaking self-assessment as part } \\
\text { of the CKC Framework. } \\
\text { - QCANWebsite source of resources to } \\
\text { complement self paced learning. }\end{array}$ & $\begin{array}{l}\text { - Higher quality practices - Exceeding } \\
\text { expectations in National Quality } \\
\text { Standard Assessment. } \\
\text { - The specific descriptors in the } \\
\text { competencles provide support for } \\
\text { the leaders to work with their staff. } \\
\text { - Leadershlp within staff team. } \\
\text { Mentoring is occurring at all levels } \\
\text { in roles and responsibilities but it } \\
\text { may take longer to see benefits } \\
\text { across the whole service. } \\
\text { - On the job training particularly for } \\
\text { unqualified staff filled the gaps } \\
\text { In knowledge about children's } \\
\text { development, effective material to } \\
\text { provide. } \\
\text { - Leaders and educators engage } \\
\text { in processes such as planning, } \\
\text { reflection and self-assessment e.g. } \\
\text { minimum one hour per week has } \\
\text { enhanced sense of importance and } \\
\text { status of roles. } \\
\text { - Increased skills in reflective practice. } \\
\text { - Leaders are able to provide more } \\
\text { direct and intensive guidance to } \\
\text { staff. } \\
\text { - Educators more motivated to use } \\
\text { CKC Framework, as they perceived } \\
\text { it had more relevance than other } \\
\text { qualifications. }\end{array}$ \\
\hline
\end{tabular}

It appears evident that the CKC Framework had a positive influence on the knowledge and confidence of leaders - see Table 4. Leaders were feeling an increased sense of professional standing, and were keen to engage with developing an OSH workforce, for example changing perspectives on recruitment of staff to seeking individuals who were keen to build a career in the OSH. This change in values and 
attitudes would support developing a workforce that could more effectively contribute to meeting the National Quality Standards for Australian Outside School Hours programs.

Table 4. Theory area two: Knowledge of OSH work.

\begin{tabular}{|c|c|c|}
\hline Context & Mechanism & Outcome \\
\hline $\begin{array}{l}\text { - Educatórs are central to } \\
\text { high quality. }\end{array}$ & $\begin{array}{l}\text { - QCAN website of resources to } \\
\text { support all aspects of competencies. } \\
\text { Articles to support deeper } \\
\text { knowledge. } \\
\text { - Leaders able to more specifically } \\
\text { describe strengths and weaknesses } \\
\text { in practices of educators. } \\
\text { - Resources to help service leaders, } \\
\text { and change practices with a focus } \\
\text { on observation. } \\
\text { - CKC Framework Handbook has } \\
10 \text { competencies that describe } \\
\text { practices and principles of daily } \\
\text { work in OSH. }\end{array}$ & $\begin{array}{l}\text { - Exceeding expectations in National } \\
\text { Quality Standard Assessment. } \\
\text { - Easier to undertake qualifications - } \\
\text { providing more detail for deepening } \\
\text { understanding of requirements. } \\
\text { - Staff appraisal is more effective } \\
\text { using the CKC Framework as the } \\
\text { basis. } \\
\text { - Leaders more articulate, informed } \\
\text { and authoritative, and find it easier } \\
\text { to ask management committee for } \\
\text { time to do training. } \\
\text { - Increased use of professional } \\
\text { language. } \\
\text { - Educators more aware of the value } \\
\text { and use of observation as a core } \\
\text { practice. }\end{array}$ \\
\hline
\end{tabular}

Table 5. Theory area three: Recruitment of staff for OSH.

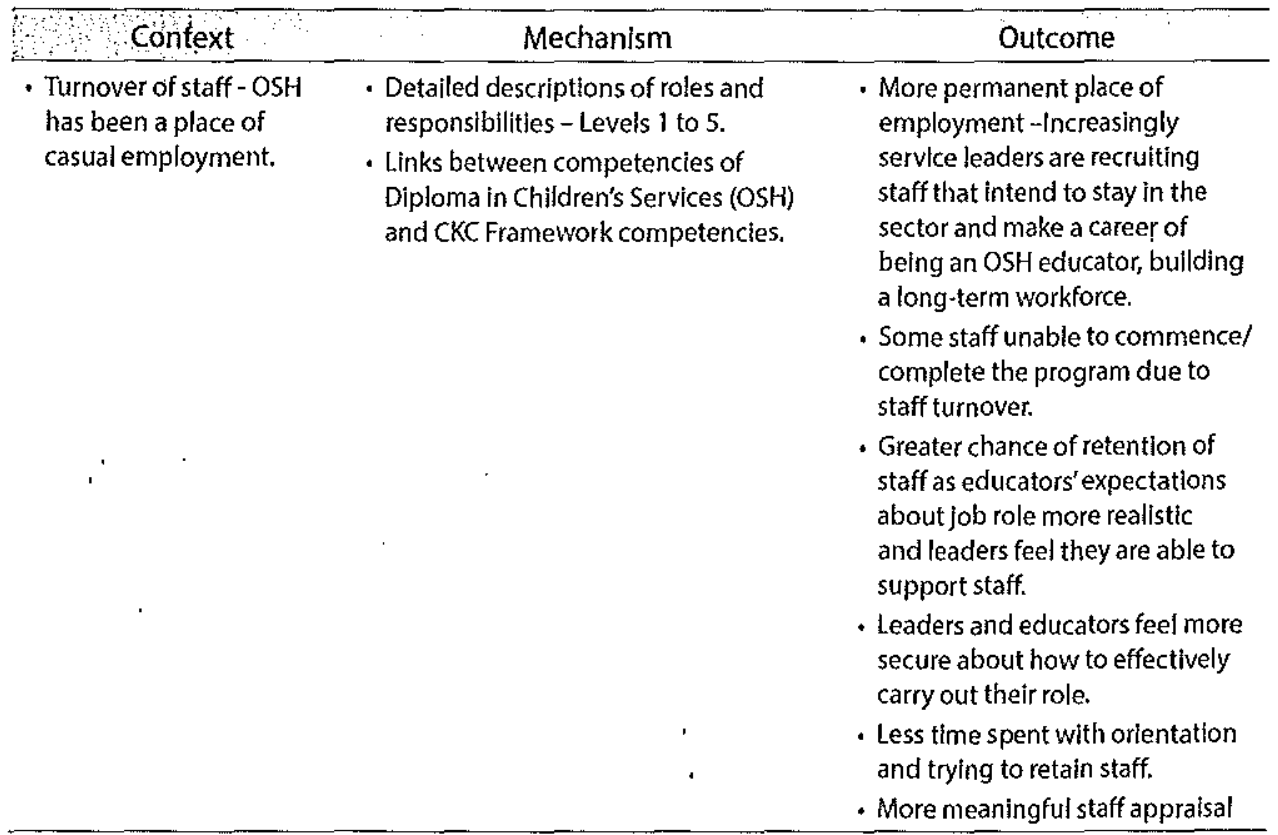


The recruitment of staff in OSH is supported by the CKC Framework - see Table 5. Working in outside school hours care is a complex job role, as there are multiple layers to the role, with expectations from several stakeholders. Due to the diversity of the backgrounds of the educators, it sometimes takes a while to establish an understanding of the parameters of the role. Having a list of the competencies as found in the CKC Framework makes it easier to transfer knowledge from the discipline area of the formal qualification to the competencies required to complete the role as educator.

\section{Limitations}

This project had a number of limitations, and these should be taken into consideration when interpreting the findings. The intervention was in its early stages and therefore extensive data could not be collected. The face-to-face method of data collection is appropriate for gaining insight into newly implemented projects, however this method of collection was difficult due to the geographic spread of the CKC Framework training throughout Queensland. It was therefore necessary to use the self-reporting survey tool to gather a response from participants. A response from participants was more likely from those who had made time to use the CKC Framework after the two training sessions. Although some of the limitations could be deemed to impact on the validity of the findings, it is important to note that the findings of realist evaluation can help trigger new studies (Pawson \& Tilley, 1997).

\section{Discussion}

The knowledge and confidence of OSH service leaders is critical to how the CKC Framework is implemented. Without competent mentors it is difficult to deliver the Framework to support educators. The expectation that an effective training program such as the CKC Framework can deliver changes to the workforce in the OSH sector is highly dependant on the capacity of the leadership.

Of note is that the CKC Framework worked in services when there was a high level of motivation and commitment by leaders of the service. The leader was able to help the staff translate the CKC Framework into knowledge and practice on a daily basis. A shortage of service leaders appears to create additional pressure; with educators sometimes promoted beyond their skills, experience and knowledge (Bretherton 2010). Further, without on-going mentoring and skills development, these leaders may subsequently 'burn out' and leave the sector (United Voice Children's Services Union, 2011). Positive staff well-being reduces staff turnover. Staff turnover has the most far-reaching and potentially long-lasting consequences to the wider community as this affects the quality of the relationships between educators and children in child care (Gable et al., 2007). Furthermore, high staff turnover can affect the quality of professional practice within the program, and can undermine the professional culture (Whitebook \& Ryan, 2011). This can have a cyclic effect on staff as it further contributes to levels of stress and depression on the employees who remain in the centre, 
which can cause further turnover (Groeneveld, Vermeer, van Ijzendoorn \& Linting, 2012). When educators do not feel equipped for the role and the aforementioned experiences, this may potentially undermine educators' capacity to provide quality care for the children in their program (Whitebook \& Ryan 2011). Using the CKC Framework designed for OSH leaders and educators contributes positively to staff culture and staff wellbeing.

\section{Conclusion}

Growing numbers of children are spending time in outside school hours programs, subsequently leaders and educators have responsibilities and roles to ensure that there are high quality outcomes for these children (DEEWR, 2011). The capacity of OSH services to meet the Australian Government mandated National Quality Standard (NQS) relies on the understanding and capabilities of the educators (ACECQA, 2013c). Leaders who became CKC Framework mentors delivered OSH programs that were meeting or exceeding the National Quality Standard, as they were able to plan, implement, analyse and evaluate their programs and practices with a high level of competence. The CKC Framework enhances the quality of the care environments; with increased capacity to engage in problem solving and critical thinking. These characteristics enhanced the capacity of OSH educators to meet the assessment ratings of the National Quality Standard, and also reduced staff turnover - a positive outcome from the CKC Framework training on staff. Increasing the capacity and competency of the educator in turn increases the outcomes for the children.

The CKC Framework has the potential to be an effective development strategy for the outside school hours workforce. Leaders of OSH programs require a skill set that allows them to mentor the educators working in services. Without access to effective leaders in OSH services it is impossible to implement the CKC Framework.

\section{References}

Australian Children's Education and Care Quality Authority (ACECQA) (2013a). Education and Care Services National Law (Queensland). Office of the Queensland Parliamentary Counsel.

Australian Children's Education and Care Quality Authority (ACECQA) (2013b). Education and Care Services National Regulations. Retrieved from http://www. legislation.nsw.gov.au/\#/view/regulation/2011/653/full

Australian Children's Education and Care Quality Authority (ACECQA) (2013c). Guide to the National Quality Standard. Retrieved from http://files.acecqa.gov. au/files/National-Quality-Framework-Resources-Kit/NQF03-Guide-to-NQS130902.pdf 
Australian Children's Education and Care Quality Authority (ACECQA) (2016). National Snapshot Q2, A quarterly report from the Australian Children's Education and Care Quality Authority, Retrieved from http://files.acecqa.gov.au/files/ Reports/2016/NQF_Snapshot_Q2 2016.pdf

Bonell, C., Fletcher, A., Morton, M., Lorenc, T., \& Moore, L. (2012). Realist randomised controlled trials: A new approach to evaluating complex public health interventions. Social Science \& Medicine, 75(12), 2299-2306. http://dx.doi. org/10.1016/j.socscimed.2012.08.032

Bretherton, T. (2010). Developing the child care workforce: Understanding 'fight' or 'flight' amongst workers. NCVER. Retrieved from http://www.ncver.edu.au/ publications/2261.html.

Brown, C. P., \& Lan, Y. C. (2014). A qualitative metasynthesis of how early educators in international contexts address cultural matters that contrast with developmentally appropriate practices. Early Education and Development, 26(1), 22-45. http://dx.doi.org/10.1080/10409289.2014.934176

Cartmel, J., \& Hayes, A. (2016). Before and after school: Literature review about Australian school age child care, Children Australia, 41(3), 201-207. http://dx. doi.org/10.1017/cha.2016.17

Cartmel, J., Macfarlane, K., Casley, M., \& Smith, K. (2015). Leading Learning Circles for Educators Engaged in Study. Retrieved from https://docs.education.gov. $\mathrm{au} /$ system/files/doc/other/learning_circles_resource_0.pdf

Davies, R., \& Dart, J. (2005). The most significant change (MSC) technique: A guide to its use. Retrieved from www.mande.co.uk/docs/MSCGuide.pdf

Department of Education, Employment and Workplace Relations (DEEWR) (2011). My time our place, Framework for school age care in Australia. Canberra: DETE. http://files.acecqa.gov.au/files/National-Quality-Framework-Resources$\mathrm{Kit} / \mathrm{my}$ time_our place_framework for_school age_care_in_australia.pdf

Elliot, R., Lawrence, M., \& Ross-Raynor, $\bar{M}$. (Eds.) (2008). Foster their culture: Caring for Aboriginal and Torres Strait Islander children in out-of-home care. Secretariat of National Aboriginal and Islander Care (SNAICC). Retrieved from http://www.snaicc.org.au/wp-content/uploads/2016/01/02515.pdf

Gable, S., Rothrauff, T., Thornburg, K., \& Mauzy, D. (2007). Cash incentives and turnover in center-based child care staff. Early Childhood Research Quarterly, 22(3), 363-378. http://dx.doi.org/10.1016/j.ecresq.2007.06.002

Gredig, D. (2011). From research to practice: Research-based intervention development in social work: developing practice through cooperative knowledge production. European Journal of Social Work, 14(1), 53-70. http://dx.doi.org/10.10 $80 / 13691457.2010 .516624$

Groeneveld, M. G., Vermeer H. J., van IJzendoorn, M., \& Linting M. (2012). Stress, cortisol and well-being of caregivers and children in home-based child care: a case for differential susceptibility. Child Care Health Development, 38(2), 25160. http://dx.doi.org/10.1111/j.1365-2214.2010.01194.x

Guilfoyle, A., Sims, M., Saggers, S., \& Hutchins, T. (2010). Culturally Strong Childcare Programs for Indigenous Children, Families and Communities. Australasian Journal of Early Childhood, 35(3), 68-76. 
Keen, R. (2011). The Development of Problem Solving in Young Children: A Critical Cognitive Skill. Annual Review of Psychology, 62, 1-21. http://dx.doi. org/10.1146/annurev.psych.031809.130730

Kielblock, S., \& Monsen, J. J. (2016). Practitioner's use of research to improve their teaching practices within extended educational contexts. International Journal for Research on Extended Education, 4(2), 5-16.

Macfarlane, K., Casley, M., Cartmel, J., \& Smith, K. (2014). Understanding the 'how': a model of practice for critical reflection for children's services practitioners. Journal of Playwork Practice, 1 (1), 47-59. http://dx.doi.org/10.1332/20 $5316214 X 13944641803030$

Macfarlane, K., Lakhani, A., Cartmel, J., Casley, M., \& Smith, K. (2015). 'Accept the change and enjoy the range': Applications of the Circles of Change methodology with professionals who support early childhood educators. Professional Development in Education, 41(2), 329-343. http://dx.doi.org/10.1080/1941525 7.2014.986816

Marschark, M., \& Johnson, H. A. (Eds.). (2008) From Research to Practice. Journal of Deaf Studies and Deaf Education 13(1).

McEvoy, P., \& Richards, D. (2003). Critical realism: a way forward for evaluation research in nursing? Joumal of Advanced Nursing, 43(4), 411-420. http://dx.doi.org/10.1046/j.1365-2648.2003.02730.x

Mezirow, J. (1997). Transformative Learning: Theory to Practice. Transformative Learning in Action New directions for Adult and Continuing Education, 74 (Summer), 5-12. http://dx.doi.org/10.1002/ace.7401

Muthivhi, A. E. (2013). Development of verbal thinking and problem-solving among TshiVenda-speaking primary school children. Perspectives in Education, 31(2), 22-141.

National After School Association (NAA) (2011). Core Knowledge and Competencies for Afterschool and Youth Development Professionals - Second Edition. Retrieved from http://naaweb.org/images/Core-Knowledge-and-Competenciesweb.pdf

National Association for the Education of Young Children (NAEYC) and Society for Research in Child Development (SRCD) (2007). Using Research to improve outcomes for young children: A call for action final report of the Wingspread Conference September 18-20, 2007. Retrieved from https://www.naeyc.org/ files/naeyc/file/research/WingspreadReport.pdf

Pawson, R. (2006). Evidence-Based Policy: A Realist Perspective. UK: Sage Publications. http://dx.doi.org/10.4135/9781849209120

Pawson, R., \& Tilley, N. (1997) Realistic Evaluation. UK: Sage Publications Ltd.

Queensland Children's Activities Network (QCAN) (2012). Intentionality in practice information paper. Queensland Government. Retrieved from http://media. wix.com/ugd/5b9443 f32514e030944d9690060f9cce2f2772.pdf

Queensland Children's Äctivities Network (QCAN) (2014a). Core Knowledge and Competency program. Developed from the National Afterschool Association (NAA) Core Knowledge and Competencies for Afterschool and Youth Development Professionals, 2011. Queensland Government. Retrieved from http://www.ckcframework.org.au 
Queensland Children's Activities Network (QCAN) (2014b). Core Knowledge and Competencies Framework (CKC) learning guide for workplace mentors. Brisbane, Australia: QCAN.

Simoncini, K., \& Lasen, M. (2012). Support for quality delivery of outside school hours care: A case study. Australasian Journal of Early Childhood, 37(2), 82-94.

Simoncini, K., Cartmel, J. \& Young, A. (2015). Children's voices in Australian school age care: what do they think about afterschool care? International Journal of Extended Education, 3(1), 114-131. http://dx.doi.org/10.3224/ijree.v3i1.19584

Snow, K. (2011). A Bridge between Early Childhood Research and Practice. Young Children 66(4), 63-65. National Association for the Education of Young Children (NAEYC). Retrieved from http://www.jstor.org/stable/42731283

United Voice Children's Services Union (2011). What's in a name? [Press release]. Retrieved from http://www.unitedvoice.org.au/news/whats-name

Whitebook, M., \& Ryan, S. (2011). Degrees in context: Asking the Right Questions about Preparing Skilled and Effective Teachers of Young Children. National Institute for Early Education Research Preschool policy brief issue 22. Retrieved from http://nieer.org/wp-content/uploads/2016/08/23-2.pdf 